\title{
AKTIVITAS DAN SELEKTIVITAS KATALIS Ni/H5NZA TERHADAP HIDRORENGKAH METIL OLEAT MENJADI SENYAWA HIDROKARBON FRAKSI PENDEK
}

\author{
Ratno Budiyanto*, Donatus. Setyawan, Novita Andarini \\ Jurusan Kimia, Fakultas Matematika dan Ilmu Pengetahuan Alam \\ Universitas Jember \\ *email : ratno.by@gmail.com
}

Received 16 April 2018

Accepted 28 Mei 2018

\begin{abstract}
Abstrak
Telah dilakukan uji aktivitas dan selektivitas katalis $\mathrm{Ni} / \mathrm{H}_{5} \mathrm{NZA}$ terhadap hidrorengkah metil oleat menjadi senyawa hidrokarbon fraksi pendek dengan variasi konsentrasi Ni 1\%,2\% dan $3 \%(\% \mathrm{~b} / \mathrm{b})$ untuk hidrorengkah katalitik metil oleat menjadi senyawa hidrokarbon fraksi pendek (hidrokarbon $\mathrm{C}_{5}-\mathrm{C}_{12}$ ). Katalis dibuat dengan metode impregnasi basah, dilanjutkan kalsinasi pada temperatur $500^{\circ} \mathrm{C}$, oksidasi pada temperatur $400^{\circ} \mathrm{C}$ dan reduksi pada $500^{\circ} \mathrm{C}$, masing-masing dengan aliran gas nitrogen, oksigen dan hidrogen dengan kecepatan gas alir $\pm 5 \mathrm{~mL} /$ detik. Karakterisasi katalis meliputi penentuan rasio $\mathrm{Si} / \mathrm{Al}$, kandungan logam Ni yang terimpregnasi dengan menggunakan alat AAS, dan penentuan keasaman dengan menggunakan metode gravimetri. Proses hidrorengkah dilakukan dalam reaktor flow-fixed bed pada temperatur $500^{\circ} \mathrm{C}$. Katalis dipanaskan terlebih dahulu kemudian reaktan dipanaskan di reaktor pirolisis secara terpisah hingga menjadi uap, kemudian dialirkan ke reaktor hidrorengkah. Cairan hasil hidrorengkah ditampung dan dianalisis dengan kromatografi gas (GC) dan kromatografi gas-spektrometer massa (GC-MS). Hasil karakterisasi menunjukkan bahwa secara umum bahwa rasio $\mathrm{Si} / \mathrm{Al}$ mengalami penurunan setelah diimpregnasi logam $\mathrm{Ni}$, sedangkan jumlah kandungan logam $\mathrm{Ni}$ hampir mencapai setengah dari konsentrasi awal Ni yang diimpregnasikan. Sedangkan jumlah keasaman katalis setelah diimpregnasikan dengan logam Ni meningkat dibandingkan katalis sebelum diimpregnasikan dengan logam Ni. Hasil penelitian menunjukkan bahwa aktivitas dan selektivitas katalis $\mathrm{Ni}-2 \% / \mathrm{H}_{5}-\mathrm{NZA}$ lebih baik dalam menghidrorengkah senyawa hidrokarbon yang lebih pendek. Aktivitas katalis Ni-2\%/H5-NZA mencapai $91.3041 \%$. Sedangkan selektivitasnya lebih selektiv terhadap pembentukan senyawa hidrokarbon rantai $\mathrm{C}_{5}-\mathrm{C}_{11}$ dan lebih mengarah pada pembentukan alkane dan alkena.
\end{abstract}

Katakunci : metil oleat, katalis, $\mathrm{Ni} / \mathrm{H}_{5} \mathrm{NZA}$ dan hidrorengkah

\begin{abstract}
It has conducted on the activity and selectivity of $\mathrm{Ni} / \mathrm{H}_{5} \mathrm{NZA}$ catalyst toward the hydrocracking of oleat methyl catalytic becomes short fraction hydrocarbon compounds with the variation of Ni concentration such as 1\%, 2\% and 3\% (\% w/w) for oleat methyl catalytic hydrocracking becomes short fraction hydrocarbon compounds $\left(\mathrm{C}_{5}-\mathrm{C}_{11}\right.$ hydrocarbon). The catalyst is prepared by wet impregnation method, then followed by calcinations at $500^{\circ} \mathrm{C}$, oxidation at $400^{\circ} \mathrm{C}$ and reduction at $500^{\circ} \mathrm{C}$, each of them are followed by a stream of nitrogen, oxygen and hydrogen with $\pm 5 \mathrm{~mL} / \mathrm{second}$ in stream velocity. The characterization of catalyst includes the determination of $\mathrm{Si} / \mathrm{Al}$ ratio, Ni metal that were impregnated by using AAS instrument, and the acid determination by using gravimetric
\end{abstract}


method. The hydrocracking process is done in flow-fixed bed reactor at $500^{\circ} \mathrm{C}$; the catalyst are heated at first and followed by the reactants which are heated in pyrolysis reactor up to it change into vapor, then they are moved into the hydrocracking reactor. The liquid from hydrocracking process is collected and analyzed by using Gas of Chromatography (GC) and Gas of Chromatography-Mass spectrometer (GC-MS). The characterization results showed in general that $\mathrm{Si} / \mathrm{Al}$ ratio decreases after being impregnated by $\mathrm{Ni}$ metal. The amount of $\mathrm{Ni}$ metal almost reach a half of early Ni concentration which is impregnated. On the other hands, the acid amount of catalyst after being impregnated by Ni metal rise higher than those before being impregnated by Ni metal. The research showed that the activity and selectivity of $\mathrm{Ni}-2 \% / \mathrm{H}_{5} \mathrm{NZA}$ catalyst is better in hydrocracking hydrocarbon compounds which are shorter. The activity of $\mathrm{Ni}-2 \% / \mathrm{H}_{5} \mathrm{NZA}$ catalyst reaches $91.3041 \%$. Meanwhile the selectivity is more selective in creating the hydrocarbon compounds with $\mathrm{C}_{5}-\mathrm{C}_{11}$ chain and more lead to the formation of alkane and alkene.

Keywords: methyl oleate, catalyst, $\mathrm{Ni} / \mathrm{H}_{5} \mathrm{NZ}$, hydrocracking

\section{Pendahuluan}

Perkembangan teknologi berbanding lurus dengan kebutuhan energi dalam bidang transportasi dan industri, sementara sumber energi yang kita pakai selama ini merupakan sumber energi fosil yang tidak dapat diperbaharui, sehingga mendorong pencarian energi alternatif sebagai pengganti sumber energi terbarukan. Pemilihan minyak sawit sebagai sumber energi sangat tepat dilakukan di Indonesia mengingat penghasil minyak kelapa sawit terbesar nomor dua di dunia setelah Malaysia. Komposisi asam lemak dalam minyak sawit memiliki jumlah kandungan terbesar setelah asam palmitat, yaitu sebesar 39\% (Hendrawati, 2017). Kandungan asam oleat yang tinggi menjadi dasar pertimbangan untuk digunakan sebagai bahan baku dalam penelitian hidrorengkah asam oleat menjadi senyawa hidrokarbon fraksi pendek.

Astutik (2005), menyatakan bahwa metil ester dari minyak jelantah dapat direngkah dengan menggunakan katalis $\mathrm{H}_{5} \mathrm{NZA}$ dengan umpan alkohol (etanol dan propanol) pada temperatur $450{ }^{\circ} \mathrm{C}$ selama \pm 30 menit dalam kolom reator sistem flow fixed bed. Jumlah katalis yang digunakan adalah sebanyak 4 gram, sedangkan jumlah metil ester yang digunakan sama dengan jumlah alkohol yaitu $7.5 \mathrm{~mL}$. Hasil Online ISSN: 2528-0422 dari perengkahan ini berupa fraksi gasoline sebesar $27.45 \%$. Pemilihan logam $\mathrm{Ni}$ sebagai pengemban dikarenakan unsur Logam Ni mempunyai orbital atom $3 \mathrm{~d}$ yang belum penuh, maka sesuai aturan Hund terdapat elektron-elektron yang belum berpasangan pada orbital $d$. Logam nikel sangat umum digunakan dalam proses hidrogenasi maupun dehidrogenasi walaupun aktivitasnya lebih lemah dibandingkan dengan aktivitas logam mulia, seperti Pd dan Pt, tetapi stabilitas termalnya cukup tinggi dan daya tahan yang besar terhadap racun katalis (Ketaren, S., 1986).

Penelitian sebelumnya menyatakan bahwa logam Ni dapat diembankan pada zeolit melalui impregnasi basah. Keberhasilan $\mathrm{Ni}^{2+}$ yang terimpregnasi dari hasil pengukuran dengan metode AAS adalah sebesar $36.24 \%$ dari konsentrasi awal nikel yang diimpregnasikan yaitu $2 \%$ (b/b) (Hasyim, 2007). Jumlah logam Ni yang diembankan memungkinkan terjadinya penumpukan logam Ni pada permukaan pori pengemban sehingga menyebabkan terhalangnya ion sejenis untuk dapat masuk kedalam pori pengemban. Sehingga pada penelitian ini variasi konsentrasi $\mathrm{Ni}$ yang terembankan adalah 1, 2 dan $3 \%$ (b/b).

Asam oleat sebelum diproses dengan katalis melalui perengkahan katalitik, 
terlebih dahulu direaksikan dengan metanol dan asam sulfat untuk membentuk metil esternya (FAME, Fatty Acid Methyl esther). Sebagaimana yang telah diteliti oleh Abiney (2008), esterifikasi asam oleat dengan menggunakan katalis $\mathrm{H}_{2} \mathrm{SO}_{4}$ menghasilkan konversi metil ester sebesar $92 \%$ dalam jangka waktu 2 jam. Selajutnya senyawa FAME di proses dengan katalis $\mathrm{Ni} / \mathrm{H}_{5}-\mathrm{NZA}$ dalam kolom reaktor sistem flow fixed bed pada temperatur $450^{\circ} \mathrm{C}$ dengan dialiri gas hidrogen sebagai carrier gas.

\section{Metodologi Penelitian}

\section{Alat dan bahan}

Alat-alat yang digunakan dalam penelitian meliputi: peralatan gelas, neraca analitik, termometer, reaktor aktivasi, reaktor katalitik jenis "flow fixed bed", oven, GC dan GC-MS, desikator vakum, AAS, pengaduk, saringan 100 mesh, wadah plastik, satu set refluks, stirer magnetik, cawan porselen, krus teflon, corong pemisah, dan kertas $\mathrm{pH}$. Bahanbahan yang digunakan dalam penelitian meliputi: Zeolit alam dari PT. Prima Zeolit Wonosari Yogyakarta, metil oleat 65\% $88 \%$, kristal $\mathrm{Ni}\left(\mathrm{NO}_{3}\right)_{2} .6 \mathrm{H}_{2} \mathrm{O} 99 \%$, gas nitogen $\left(\mathrm{N}_{2}\right)$, gas oksigen $\left(\mathrm{O}_{2}\right)$, gas hidrogen $\left(\mathrm{H}_{2}\right)$, larutan $\mathrm{HF} 1 \%$, larutan $\mathrm{HCl}$ $3 \mathrm{M}$, larutan $\mathrm{NH}_{4} \mathrm{Cl} 1 \mathrm{M}$, larutan $\mathrm{NH}_{3} 25 \%$ pa (gas $\mathrm{NH}_{3}$ ), glass wool dan aquades.

\section{Prosedur penelitian}

\section{Preparasi katalis}

Zeolit alam dari Wonosari, Yogyakarta dalam bentuk butiran dihaluskan dengan saringan lolos 100 mesh dan direndam dalam akuadaes sambil diaduk, dikalsinasi dengan dialiri gas nitrogen $\left(500{ }^{\circ} \mathrm{C}, 4 \mathrm{jam}\right)$ dan dioksidasi dengan oksigen $\left(400{ }^{\circ} \mathrm{C}, 2\right.$ jam) sehingga diperoleh katalis NZ.

Katalis NZ direndam dalam larutan HF $1 \%$ (volume 1:2), kemudian disaring dan dicuci berulang-ulang dengan akuades $(\mathrm{pH}=6)$. Katalis $\mathrm{NZ}$ direfluks dengan $\mathrm{HCl}$ $3 \mathrm{M} \quad\left(90^{\circ} \mathrm{C}, \quad 30\right.$ menit $)$. Setelah itu dilanjutkan dengan penyaringan dan pencucian dengan akuades $(\mathrm{pH}=6)$ sehingga diperoleh katalis NZA.

Katalis NZA direfluks dalam larutan $\mathrm{NH}_{4} \mathrm{Cl} 1 \mathrm{M}$ (volume $1: 2,90^{\circ} \mathrm{C}, 3 \mathrm{jam}$ ) selama satu minggu dan diaduk setiap satu jam selama pemanasan. Disaring dan dicuci dengan akuades $(\mathrm{pH}=6)$, dikeringkan dalam oven $\left(120^{\circ} \mathrm{C}\right)$. Dikalsinasi (4 jam, $500^{\circ} \mathrm{C}$ ) dalam Muffle Furnace (kalsinasi tanpa gas nitrogen). Sampel didinginkan dan dilanjutkan dengan proses hidrotermal $\left(500^{\circ} \mathrm{C}, 5 \mathrm{jam}\right)$, dikalsinasi dengan gas nitrogen $\left(500^{\circ} \mathrm{C}, 3\right.$ jam), dioksidasi dengan gas oksigen $\left(400^{\circ} \mathrm{C}, 2 \mathrm{jam}\right)$ sehinnga diperoleh katalis $\mathrm{H}_{5} \mathrm{NZA}$.

Pembuatan katalis Ni-Zeolit melalui impregnasi logam nikel yaitu merendam katalis $\mathrm{H}_{5} \mathrm{NZA}$ ke dalam larutan $\mathrm{Ni}\left(\mathrm{NO}_{3}\right)_{2} \cdot 6 \mathrm{H}_{2} \mathrm{O}\left(90{ }^{\circ} \mathrm{C}, 3\right.$ jam $)$ dengan variasi konsentrasi 1, 2 dan $3 \%(\mathrm{~b} / \mathrm{b})$. Dikalsinasi dengan gas nitrogen kedalam reaktor $\left(500{ }^{\circ} \mathrm{C}, 3\right.$ jam $)$ dengan kecepatan $\pm 5 \mathrm{~mL} /$ detik, dilanjutkan dengan proses oksidasi dengan mengalirkan gas oksigen dengan kecepatan $\pm 5 \mathrm{~mL} /$ detik $\left(500^{\circ} \mathrm{C}, 2\right.$ jam) dan direduksi dengan mengalirkan gas $\mathrm{H}_{2}$ sehinnga didapatkan katalis $\mathrm{Ni} / \mathrm{H}_{5}-$ NZA.

\section{Karakterisasi katalis}

Penentuan keasaman total katalis dilakukan secara gravimetri atas dasar adsorpsi kimia gas amonia oleh situs asam pada permukaan zeolit. Sebanyak 3 gram sampel dipanaskan sampai temperatur 120 ${ }^{\circ} \mathrm{C}$ selama 2 jam. Didinginkan dalam desikator dan ditimbang hingga berat tetap (W) dalam mg sampel. Sampel kemudian ditempatkan dalam desikator kembali dan desikator divakumkan lalu sampel didesikator dialiri gas $\mathrm{NH}_{3}$ yang berasal dari $\mathrm{NH}_{4} \mathrm{OH}$ yang dipanaskan pada temperatur $\pm 60^{\circ} \mathrm{C}$ hingga kelihatan uap di dalam desikator (kondisi jenuh). Selanjutnya didinginkan selama 24 jam. Setelah itu ditimbang hingga diperoleh berat tetap $\left(\mathrm{W}^{1}\right)$ dalam $\mathrm{mg}$ berat katalis. Setelah itu sampel diangin-anginkan selama 15 menit dan ditimbang berulang- 
ulang setiap 15 menit hingga diperoleh berat tetap. Keasaman disini didefinisikan sebagai jumlah (mmol) $\mathrm{NH}_{3}$ yang teradsorpsi untuk setiap gram berat katalis.

Penentuan rasio $\mathrm{Si} / \mathrm{Al}$ total pada penelitian ini dilakukan dengan alat AAS Kation $\mathrm{Si}$ ditentukan sebagai $\mathrm{SiO}_{2}$ dan $\mathrm{Al}$ ditentukan sebagai $\mathrm{Al}_{2} \mathrm{O}_{3}$. Kandungan logam yang terimpregnasi dalam katalis $\mathrm{H}_{5} \mathrm{NZA}$ juga ditentukan dengan AAS.

\section{Uji aktivitas dan selektivitas katalis}

Sebanyak 5 gram katalis ditempatan dalam kolom reaktor kemudian dipanaskan hingga temperatur $450^{\circ} \mathrm{C}$. Selanjutnya gas hidrogen sebagai "gas pembawa" dialirkan melalui evaporator yang telah diisi umpan metil oleat sebanyak $10 \mathrm{~mL}$. Kolom evaporator dipanaskan sehingga uap metil oleat bersama gas hidrogen mengalir melalui reaktor yang telah ditempatkan katalis pada suhu $450^{\circ} \mathrm{C}$ (gambar 1). Diharapkan dalam kolom reaktor terjadi reaksi katalitik dan produk yang dihasilkan kemudian ditampung dan dilakukan analisis dengan GC dan GC-MS.

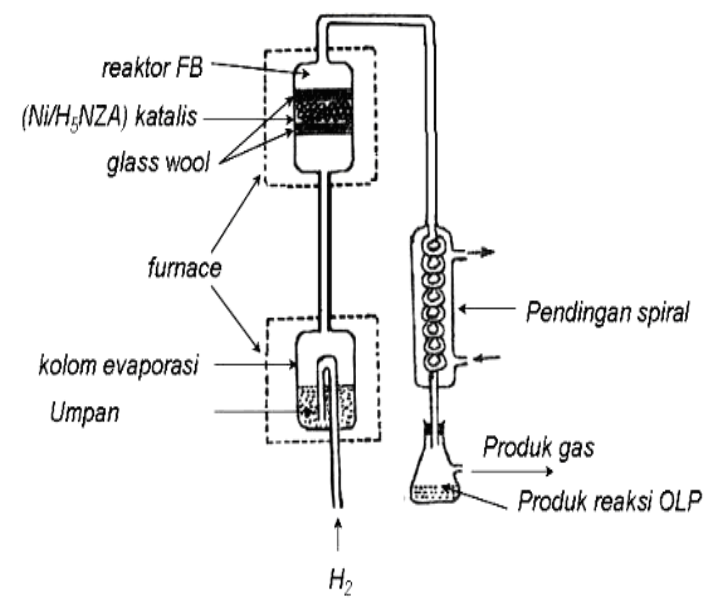

Gambar 1. Reaktor flow fixed bed sebagai alat hiddrorengkah katalitik

Aktivitas $(A)$ ditentukan sesuai dengan persamaan 1 , dengan produk reaksi $(P)$ dan reaktan yang merupakan metil oleat dan asam oleat $(R)$ Adapun selektivitas $(S)$ ditentukan sesuai persamaan 2, dengan jumlah molekul target $\left(P_{i}\right)$.

$$
\begin{aligned}
& A(\%)=\frac{P}{R} 100 \% \\
& \mathrm{~S}(\%)=\frac{P_{i}}{R} 100 \%
\end{aligned}
$$

\section{Hasil dan Pembahasan}

\section{Keasaman katalis}

Berdasarkan gambar 2, modifikasi katalis NZ memiliki keasaman relatif rendah jika dibandingkan dengan modifikasi katalis lainnya. Selain adanya pengotor pada Natural Zeolit (NZ) yang mengakibatkan adanya akumulasi pada mulut pori dan juga belum adanya perlakuan asam, karena dengan adanya perlakuan asam mampu menyediakan tambahan situs aktif pada katalis. Dua macam situs asam yang dapat terbentuk akibat preparasi serta pengembanan yaitu situs asam Bronsted dan asam Lewis. Dampak akumulasi pengotor pada mulut pori dan tidak adanya dua situs asam aktif tersebut mengakibatkan daya adsorpsi terhadap gas amonia kurang maksimal. Sedangkan katalis NZA yang melalui pengasaman menunjukkan adanya peningkatan, demikian juga dengan katalis $\mathrm{H}_{5}$ NZA yang telah terjadi reaksi kimia dengan larutan garam $\mathrm{NH}_{4} \mathrm{Cl}$, yakni pertukaran ion $\mathrm{NH}_{4}{ }^{+}$dengan logam yang ada di zeolit membentuk $\mathrm{H}$ - zeolit.

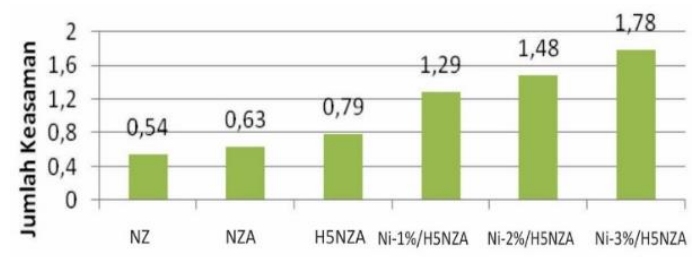

Gambar 2. Keasaman Katalis

Peningkatan keasaman juga terjadi setelah diimpregnasikannya logam $\mathrm{Ni}$. Mengutip jurnal Kadarwati (2013) menyatakan bahwa keberadaan logam $\mathrm{Ni}$ sebagai pengemban meningkatkan 
keasaman dibandingkan tanpa pengemban, yaitu mencapai $11.09 \times 10^{-4}$. Hal ini dikarenakan logam transisi memiliki elektron yang tidak berpasangan orbital $d$ sehingga dapat menjadi akseptor pasangan elektron dari $\mathrm{NH}_{3}$ yang memiliki dua pasang elektron bebas. Ni yang teremban pada zeolit akan membentuk asam lewis, sehingga akan berkontribusi pada kenaikan keasaman total katalis.

\section{Rasio Si/Al}

Berdasarkan gambar 3, dapat dijelaskan bahwa katalis NZ memiliki rasio $\mathrm{Si} / \mathrm{Al}$ paling rendah jika dibandingkan dengan modifikasi katalis lainnya. Kenaikan rasio Si/Al dari katalis NZ sampai katalis $\mathrm{H}_{5} \mathrm{NZA}$ terjadi karena adanya proses dealuminasi melalui refluks dengan $\mathrm{HCl}$ $3 \mathrm{M}$ dan proses hidrotermal. Kaitannya dengan rasio $\mathrm{Si} / \mathrm{Al}$ tidak terlepas dari perlakuan hidrotermal sebelum perlakuan impregnasi dengan logam $\mathrm{Ni}$, tujuannya adalah agar katalis tersebut stabil pada temperatur tinggi yang ditandai dengan adanya pergantian posisi Al pada zeolit oleh Si yang menyebabkan jarak antara $\mathrm{Al}$ dan Si lebih dekat karena tidak banyak lagi kandungan $\mathrm{Al}$ yang ada dalam katalis sehingga katalis tersebut lebih kuat dan rigit.

Penurunan rasio $\mathrm{Si} / \mathrm{Al}$ terjadi setelah diimpregnasikannya logam $\mathrm{Ni}$, fenomena ini bisa jadi pada saat perlakuan impregnasi dengan $\mathrm{Ni}$ situs aktifnya tertutupi oleh $\mathrm{Al}_{2} \mathrm{O}_{3}$ atau bisa dikatakan bahwa posisi $\mathrm{Si}$ sudah mengalami desilikonisasi yang begitu rendah. Penambahan logam 3\% Ni mengalami peningkatan Rasio Si/Al jika dibandingkan dengan $2 \% \mathrm{Ni}$, bisa jadi keberadaan logam $\mathrm{Ni}$ menyebabkan interkalasi atau defectcrystal pada bidang kristal zeolit, yaitu penataan Penataan ulang ini meningkatkan rasio $\mathrm{Si} / \mathrm{Al}$ dan penggantian atom $\mathrm{Al}$ oleh atom $\mathrm{Si}$ mengakibatkan terjadinya penyusutan ukuran unit kerangka dengan mengecilnya ukuran pori sehingga meningkatkan kestabilan struktur kerangka. Meskipun rasio $\mathrm{Si} / \mathrm{Al}$ mengalami penurunan, bukan berarti katalis tersebut tidak bisa bekerja secara maksimal, terbukti produk yang dihasilkan dengan adanya $\mathrm{Ni}$ lebih banyak jika dibandingkan sebelum di modifikasi dengan logam $\mathrm{Ni}$

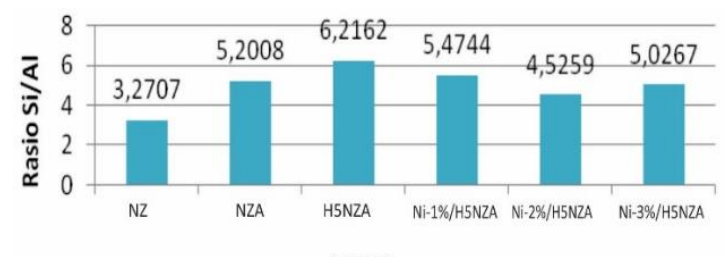

Gambar 3. Rasio Si/Al pada Katalis

\section{Kandungan Ni terimpregnasi}

Berdasarkan gambar 4, kadar logam Ni yang teremban pada zeolit mengalami peningkatan seiring dengan bertambahnya konsentrasi larutan $\mathrm{Ni}\left(\mathrm{NO}_{3}\right)_{2}$ yang diembankan dalam bentuk garam nitratnya $\mathrm{Ni}\left(\mathrm{NO}_{3}\right)_{2} \cdot 6 \mathrm{H}_{2} \mathrm{O}$. Hal ini dikarenakan potensial kimia larutan lebih besar dibandingkan dengan potensial kimia pengemban, yang mengakibatkan terjadinya gerakan ion $\mathrm{Ni}^{2+}$ teradsorpsi ke dalam padatan pengemban. Semakin besar beda potensial kimia antara larutan dengan pengemban, semakin mudah ion $\mathrm{Ni}^{2+}$ teradsorpsi pada pengemban. Berdasarkan jurnal Kadarwati (2013) Potensial kimia larutan berbanding lurus dengan konsentrasi ion $\mathrm{Ni}^{2+}$. Makin tinggi konsentrasi larutan, potensial kimia juga makin besar sehingga makin banyak $\mathrm{Ni}^{2+}$ yang teradsorpsi. Alasan kedua, adalah dengan peningkatan konsentrasi $\mathrm{Ni}^{2+}$ dalam larutan, maka frekuensi tumbukan antara partikel semakin besar sehingga efisiensi adsorpsi semakin besar. Pada proses pertukaran ion, jumlah partikel logam dalam pengemban ditentukan oleh sisi aktif pengemban yang terdapat dalam jumlah yang terbatas. Tidak semua sisi aktif itu dapat ditempati oleh kation logam sebab terdapat faktor sterik sebagai penghalang (Catherina M., 2002). 


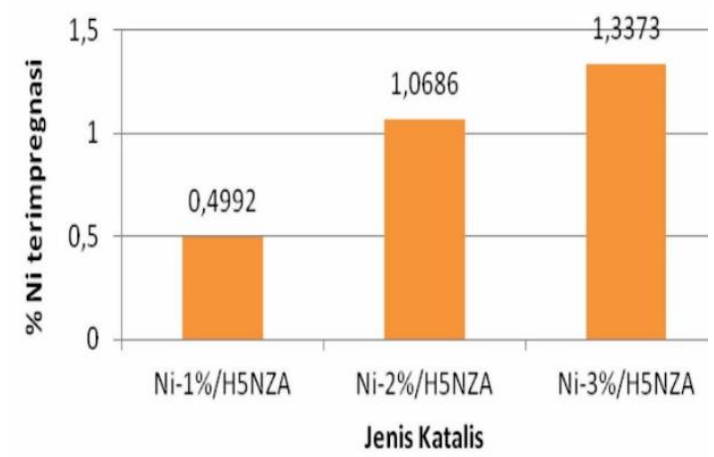

\section{Gambar 4}

\section{Hasil analisis metil oleat}

Berdasarkan gambar 5, dapat dijelaskan bahwa produk metil oleat yang digunakan dalam penelitian ini memiliki tingkat kemurnian yang tergolong masih rendah, hal ini diperkuat dengan munculnya kromatogram puncak lainnya, yang menandakan bahwa hasil esterifikasi yang dihasilkan kurang murni. Waktu retensi dari puncak-puncak tersebut cukup besar, ini berarti bahwa metil ester dari asam oleat kurang volatil sehingga senyawasenyawa yang termasuk fraksi pendek mungkin tertahan lebih lama dalam kromatografi gas.

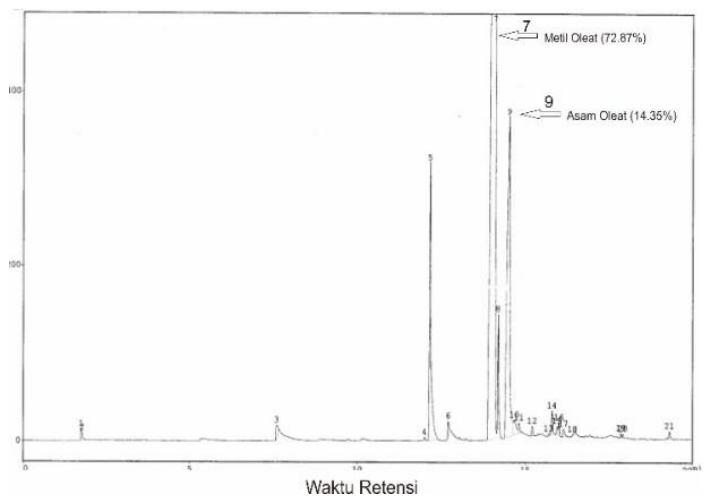

Gambar 5. Kromatogram metil oleat hasil esterifikasi asam oleat dengan GC

Dari 21 puncak yang dihasilkan, diambil 2 puncak dominan pada kromatogram yang dihasilkan yaitu senyawa metil ester oleat pada waktu retensi 14.095 menit dengan konsentrasi $72.87 \%$ dan asam oleat pada waktu retensi 14.514 menit dengan konsentrasi $14.35 \%$. Kedua senyawa ini dijadikan sebagai reaktan untuk proses hidrorengkah selanjutnya melihat jumlah kedua senyawa tersebut yang dihasilkan begitu dominan yaitu sebesar $87.23 \%$.

\section{Hidrorengkah termal}

Hidrorengkah termal metil ester oleat dilakukan pada temperatur $450^{\circ} \mathrm{C}$ terhadap $10 \mathrm{~mL}$ reaktan menggunakan set alat flow fixe bed. Pemanasan reaktor diatur agar reaktor mencapai temperatur $450^{\circ} \mathrm{C}$. Kemudian hasil produk dihentikan setelah 30 menit dari pertama kali menetesnya produk. Dari $10 \mathrm{~mL}$ metil ester yang dihidrorengkah secara termal ternyata dihasilkan produk sebanyak $\pm 5 \mathrm{~mL}$ berwarna kuning kecoklatan dalam bentuk cair. Hasil dari kromatogram hidrorengkah secara termal dijadikan sebagai pembanding untuk mengetahui pengaruh katalis $\mathrm{H}_{5} \mathrm{NZA}, \mathrm{Ni}-1 \% / \mathrm{H}_{5} \mathrm{NZA}, \quad \mathrm{Ni}-$ $2 \% / \mathrm{H}_{5} \mathrm{NZA}$ dan $\mathrm{Ni}-3 \% / \mathrm{H}_{5} \mathrm{NZA}$ dalam proses hidrorengkah katalitik.

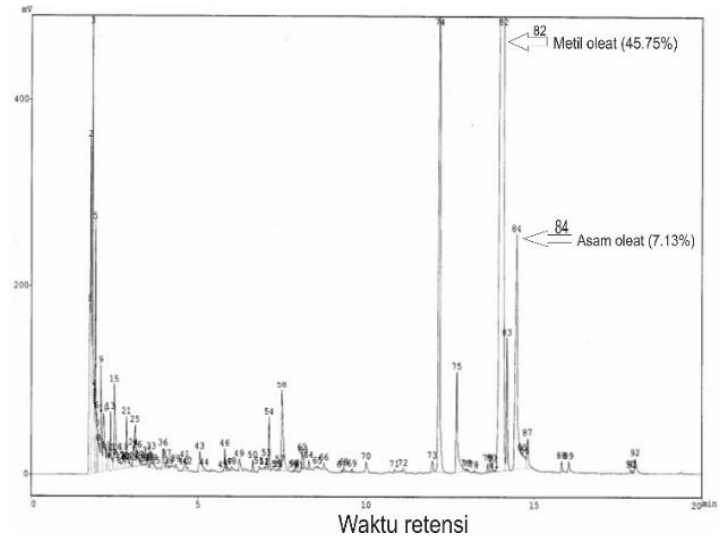

Gambar 6. Kromatogram FAME secara termal cracing dengan GC

Berdasarkan hasil analisis GC, proses secara termal menghasilkan beberapa senyawa baru. Hal ini ditunjukkan dengan munculnya puncak-puncak baru bila dibandingkan dengan kromatogram awal reaktan hasil esterifikasi. Kromatogram tersebut memperlihatkan puncak yang terbaca berada pada rentang waktu retensi dari 1.752 menit sampai 18.010 menit dengan puncak-puncak yang terbaca sejumlah 92 puncak. Terdapat 2 puncak yang dominan yaitu produk reaktan berupa 
metil oleat $45.75 \%$ dan asam oleat $7.13 \%$. Munculnya puncak-puncak baru ini menandakan bahwa terdapat senyawa baru terjadi karena adanya peristiwa pemutusan senyawa metil oleat dan asam oleat menjadi senyawa baru yang di proses secara termal. Jumlah produk yang dihasilkan secara termal adalah sebesar $47.11 \%$ yaitu jumlah senyawa hidrokarbon ditambah dengan jumlah produk perengkahan senyawa non hidrokarbon. Hasil yang diperoleh melalui proses termal hidrorengkah masih tergolong rendah. Hal ini dimungkinkan karena konsentrasi radikal bebas yang terbentuk sedikit. Proses perengkahan termal terjadi melalui mekanisme radikal bebas. Radikal bebas yang terlibat dalam proses ini berasal dari pemutusan ikatan $\mathrm{C}-\mathrm{C}$ (homolisis ikatan karbon) (Gates et.al, 1979). Sehingga produk radikal pada tahap pembentukan produk yang terjadi melalui penggabungan radikal bebas tidak terlalu banyak.

\section{Hidrorengkah katalitik [Ni/ $\left.\mathrm{H}_{5} \mathrm{NZA}\right]$}

Hidrorengkah katalitik terhadap senyawa awal (FAME) dengan menggunakan katalis $\mathrm{H}_{5} \mathrm{NZA}, \quad \mathrm{Ni}-$ $1 \% / \mathrm{H}_{5} \mathrm{NZA}, \quad \mathrm{Ni}-2 \% / \mathrm{H}_{5} \mathrm{NZA}$ dan $\mathrm{Ni}-$ $3 \% / \mathrm{H}_{5} \mathrm{NZA}$ pada temperatur tinggi $\left(450^{\circ} \mathrm{C}\right)$ dengan mengalirkan gas $\mathrm{H}_{2}$ sebagai gas pembawa dalam proses hidrorengkah bertujuan untuk mengetahui seberapa besar pengaruh kinerja katalis hasil modifikasi jika dibandingkan proses hidrorengkah secara termal. Sehingga aktivitas dan selektivitas dari masing masing katalis bisa diketahui dalam menghidrorengkah reaktan menjadi senyawa yang lebih pendek. Hasil analisis yang digunakan berupa alat kromatografi gas pada semua proses hidrorengkah dengan berbagai katalis dan analisis tambahan menggunakan alat kromatografi gas spektum massa (GC-MS) untuk hasil hidrorengkah dengan katalis $\mathrm{Ni}-$ $1 \% / \mathrm{H}_{5} \mathrm{NZA}$. Hasil Kromatogram pada kromatogram $\mathrm{GC} \mathrm{Ni}-1 \% / \mathrm{H}_{5} \mathrm{NZA}$ akan disamakan profil puncaknya dari puncak - puncak kromatogram GC-MS Ni$1 \% / \mathrm{H}_{5} \mathrm{NZA}$ yang terlihat seperti gambar 7 .

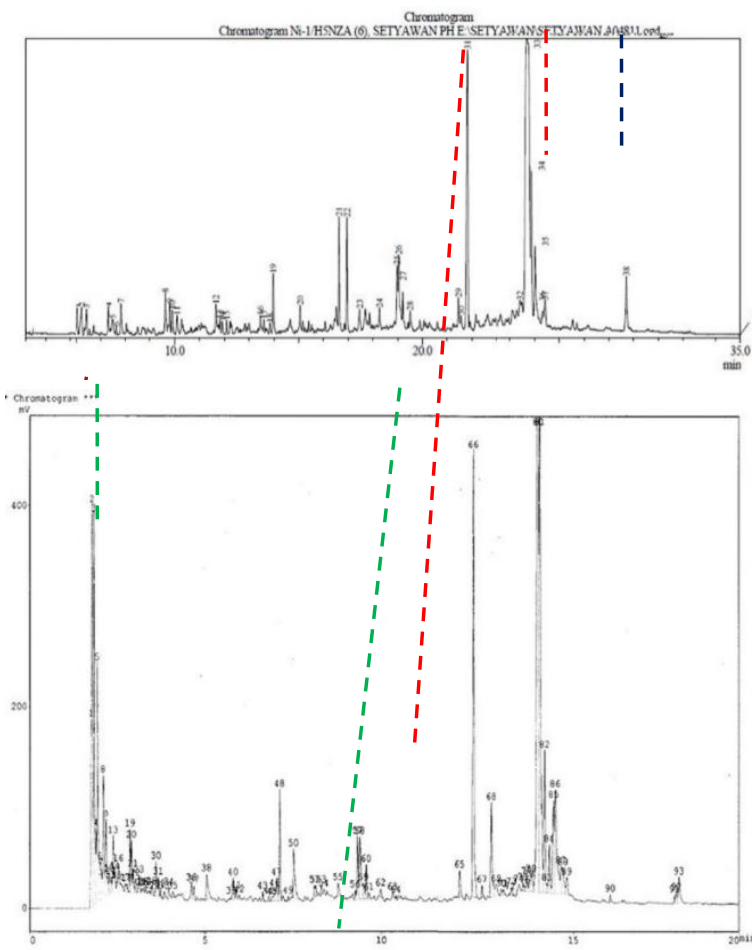

Gambar 7. Kromatogram GC-MS Ni$1 \% / \mathrm{H}_{5} \mathrm{NZA}$ dan GC Ni-1\%/H $5 \mathrm{NZA}$

Hal ini dilakukan untuk mendapatkan informasi senyawa - senyawa apa saja yang terbentuk pada proses hidrorengkah pada tiap-tiap katalis. Selanjutnya untuk hasil kromatogram dari katalis lain akan disamakan dengan cara mensejajarkan seluruh hasil kromatogram (gambar 8). Sehingga dengan cara ini akan didapatkan puncak yang sama dengan kromatogram GC $\mathrm{Ni}-1 \% / \mathrm{H}_{5} \mathrm{NZA}$ yang sebelumnya disamakan dengan profil puncak pada kromatogram GC-MS Ni-1\%/H5NZA.

Sebaran senyawa yang diketahui seperti yang tercantum pada kromatogram gambar 8 , kemudian dikelompokkan sesuai jumlah atomnya, yaitu senyawa-senyawa $\mathrm{C}_{5}-\mathrm{C}_{11}$ (fraksi pendek), $\mathrm{C}_{12}-\mathrm{C}_{18}$ (fraksi sedang) dan $\mathrm{C}_{19}-\mathrm{C}_{25}$ (fraksi berat). Senyawa senyawa diatas kemudian dikelompokkan lagi berdasarkan jenisnya, yaitu parafin, olefin, naften, asam karboksilat, aromatik, metil ester, aldehid dan keton (Tabel 1). 


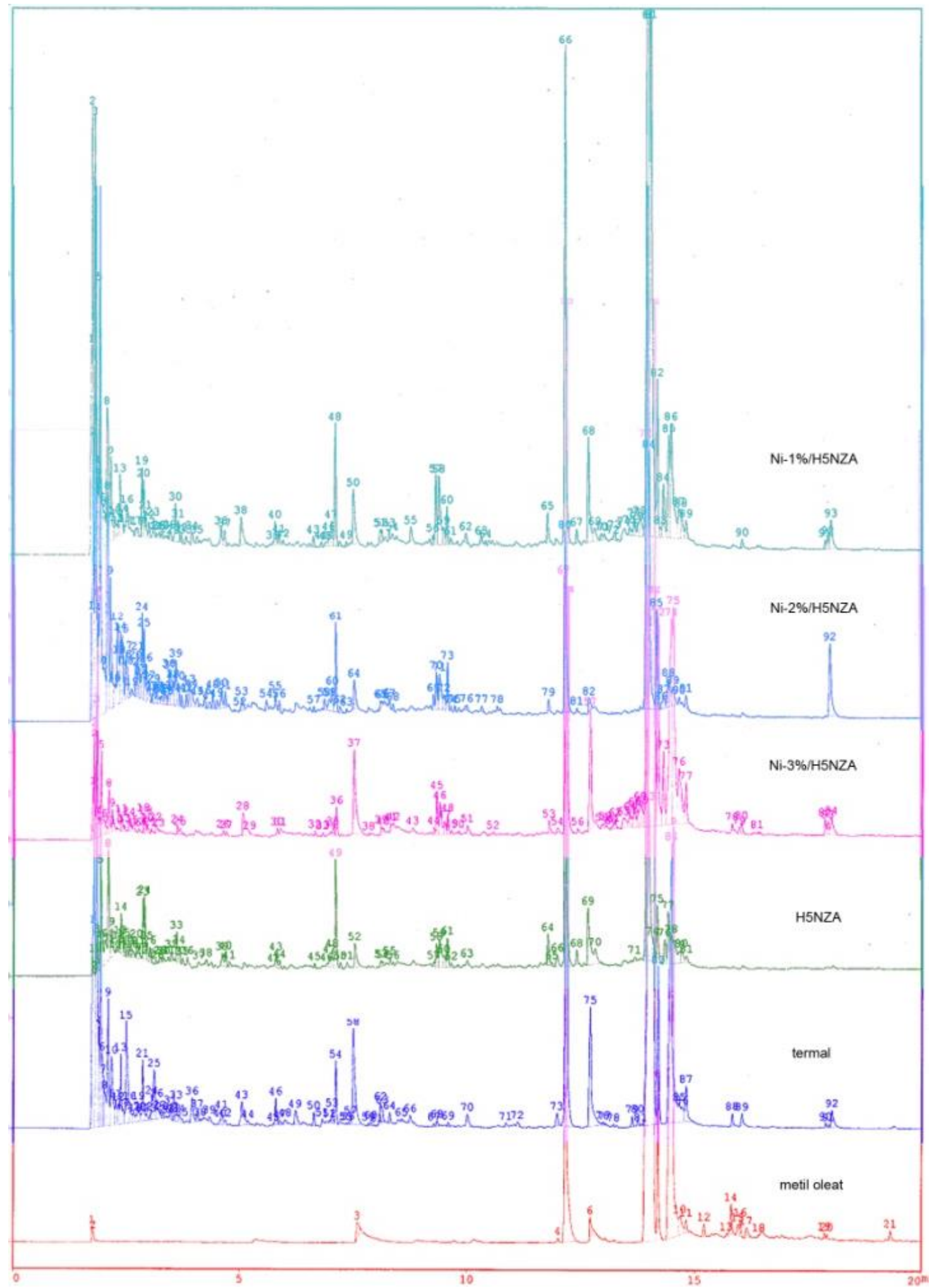

Gambar 8. Kromatogram GC dari Ni-1\%/H $\mathrm{H}_{5} \mathrm{NZA}, 2 \% / / \mathrm{H}_{5} \mathrm{NZA}, 3 \% / / \mathrm{H}_{5} \mathrm{NZA}, \mathrm{H}_{5} \mathrm{NZA}$ dan Termal yang sudah disejajarkan dengan kromatogram GC-MS Ni-1\%/H $\mathrm{H}_{5} \mathrm{NZA}$.

Berdasarkan tabel 1 dapat diketahui bahwa produk alkana dan alkena memiliki konsentrasi yang cukup besar dibandingkan dengan produk lain yang dihasilkan. Dengan adanya pengembanan logam Ni tampak bahwa terjadi peningkatan jumlah produk terutama dalam bentuk olefin dan paraffin. 
Tabel 1. Sebaran senyawa dalam FAME yang telah di analisis dengan GC

\begin{tabular}{|c|c|c|c|c|c|c|}
\hline \multirow{2}{*}{\multicolumn{2}{|c|}{ Konsentrasi senyawa (\%) }} & \multicolumn{5}{|c|}{ Jenis Perengkahan } \\
\hline & & \multirow{2}{*}{$\frac{\text { TERMAL }}{3.7141}$} & \multirow{2}{*}{$\frac{\mathrm{H}_{5}-\mathrm{NZA}}{0.0343}$} & \multirow{2}{*}{$\begin{array}{c}\text { Ni-1\%/ } \\
\mathrm{H}_{5} \mathrm{NZA} \\
4.9403\end{array}$} & \multirow{2}{*}{$\begin{array}{c}\mathrm{Ni}-2 \% / \\
\mathrm{H}_{5} \mathrm{NZA} \\
5.9132\end{array}$} & $\mathrm{Ni}-3 \% / \mathrm{H}_{5} \mathrm{NZA}$ \\
\hline \multirow{9}{*}{$\begin{array}{c}\text { Senyawa } \mathrm{C}_{6-} \\
\mathrm{C}_{11}\end{array}$} & Parafin & & & & & 0.8944 \\
\hline & Olefin & 6.0130 & 5.4953 & 9.3431 & 15.9504 & 2.223 \\
\hline & Naften & - & - & - & - & - \\
\hline & Aromatik & - & - & - & - & - \\
\hline & $\begin{array}{l}\text { asam } \\
\text { karboksilat }\end{array}$ & - & - & - & - & - \\
\hline & metil ester & 1.9684 & 5.2805 & 1.8401 & 6.7205 & 0.6105 \\
\hline & Aldehid & 2.3032 & 0.6793 & 2.3934 & 0.0437 & 0.6295 \\
\hline & Keton & - & - & - & - & - \\
\hline & Siklo & - & - & - & - & - \\
\hline \multirow{9}{*}{$\begin{array}{l}\text { Senyawa } \\
\mathrm{C}_{12}-\mathrm{C}_{18}\end{array}$} & Parafin & 0.8175 & 4.0893 & 3.0407 & 3.8296 & 0.6794 \\
\hline & Olefin & 1.9146 & 3.3046 & 1.2858 & 2.9383 & 1.0884 \\
\hline & Naften & - & - & - & - & - \\
\hline & Aromatik & 0.2456 & 1.1797 & 0.1005 & 0.1498 & 0.1786 \\
\hline & $\begin{array}{l}\text { asam } \\
\text { karboksilat }\end{array}$ & 0.2456 & 0.2372 & 0.2057 & 0.1123 & 0.1457 \\
\hline & metil ester & 1.9188 & 1.5173 & 1.6891 & 6.6687 & 10.9902 \\
\hline & Aldehid & 0.5828 & 2.4592 & 0.1247 & 1.1439 & 6.0355 \\
\hline & Keton & 0.1884 & 0.6170 & 0.4599 & 0.2786 & 0.1081 \\
\hline & Siklo & - & - & - & - & - \\
\hline \multirow{9}{*}{$\begin{array}{l}\text { Senyawa } \mathrm{C}_{19} \\
{ }_{-} \mathrm{C}_{25}\end{array}$} & Parafin & - & - & - & - & - \\
\hline & Olefin & - & - & - & - & - \\
\hline & Naften & - & - & - & - & - \\
\hline & Aromatik & 0.3248 & 2.7905 & 0.7474 & 0.2915 & 0.4671 \\
\hline & $\begin{array}{l}\text { asam } \\
\text { karboksilat }\end{array}$ & 2.1373 & 1.1797 & 2.0993 & 0.4255 & 2.1936 \\
\hline & metil ester & 0.7629 & 3.2253 & 0.5275 & 1.3361 & 4.6344 \\
\hline & Aldehid & - & - & - & - & - \\
\hline & Keton & - & - & - & - & - \\
\hline & Siklo & - & - & - & - & - \\
\hline \multicolumn{2}{|l|}{ Unknown } & 15.7272 & 39.8638 & 34.1510 & 20.3549 & 55.0418 \\
\hline
\end{tabular}

Aktivitas dan selektivitas katalis

Berdasarkan tabel 2, aktivitas katalis $\mathrm{H}_{5}$-NZA memiliki aktivitas terendah dalam proses hidrorengkah FAME, ini menandakan bahwa aktivitas katalitiknya hanya bergntung pada aktivitas katalitik zeolitnya saja, sedangkan pada katalis yang diemban dengan logam $\mathrm{Ni}$ aktivitas katalitiknya bertambah karena ada kontribusi katalitik dari logam Ni.
Berdasarkan data jumlah produk hidrorengkah, diketahui bahwa katalis Ni$2 \% / \mathrm{H}_{5}$-NZA menghasilkan produk senyawa baru paling banyak dibandingkan dengan katalis lainnya. Hal ini berarti katalis $\mathrm{Ni}-2 \% / \mathrm{H}_{5}-\mathrm{NZA}$ memiliki aktivitas tertinggi dalam pembentukan produk hidrorengkah terhadap FAME. Jika dilihat dari keasaman katalis, Justru katalis Ni$3 \% / \mathrm{H}_{5}-\mathrm{NZA}$ yang memiliki keasamaan 
paling baik dan jumlah Ni yang teremban paling besar dibandingkan dengan kataliskatalis yang lainnya, tetapi hasil hidrorengkah tampak bahwa katalis $\mathrm{Ni}$ $3 \% / \mathrm{H}_{5}-\mathrm{NZA}$ memiliki aktivitas pembentukan produk kurang baik daripada katalis Ni-zeolit lainnya. Hal ini dikarenakan logam Ni yang teremban pada katalis $\mathrm{Ni}-3 \% / \mathrm{H}_{5}-\mathrm{NZA}$ diduga terdistribusi kurang merata dan menumpuk pada permukaan pori katalis $\mathrm{H}_{5}$-NZA sehingga akan mengurangi sisi aktif katalis, akibatnya aktivitas katalis menurun. Semakin besar kadar logam Ni yang diembankan dapat mengakibatkan distribusi yang kurang merata dan hanya terakumulasi pada titik tertentu yang dapat menutupi permukaan katalis sehingga berakibat aktivitas dari katalis tidak semakin baik. Keadaan inilah yang terjadi pada katalis Ni-3\%/H5-NZA sebab dilihat dari semakin meningkatnya kadar logam $\mathrm{Ni}$ yang teremban pada katalis $\mathrm{Ni}-1 \% / \mathrm{H}_{5}-$ $\mathrm{NZA}$, dan Ni-2\%/H5-NZA menunjukkan kenaikan aktivitas katalis, tetapi pada katalis $\mathrm{Ni}-3 \% / \mathrm{H}_{5}-\mathrm{NZA}$ aktivitas katalis menurun. pada titik tertentu yang dapat menutupi permukaan katalis sehingga berakibat aktivitas dari katalis tidak semakin baik. Keadaan inilah yang terjadi pada katalis Ni-3\%/H5-NZA sebab dilihat dari semakin meningkatnya kadar logam $\mathrm{Ni}$ yang teremban pada katalis $\mathrm{Ni}-1 \% / \mathrm{H}_{5}-$ $\mathrm{NZA}$, dan $\mathrm{Ni}-2 \% / \mathrm{H}_{5}-\mathrm{NZA}$ menunjukkan kenaikan aktivitas katalis, tetapi pada katalis $\mathrm{Ni}-3 / \mathrm{H}_{5}-\mathrm{NZA}$ aktivitas katalis menurun.

Pada Fraksi sedang (kerosin) dengan rantai karbon $\mathrm{C}_{12}-\mathrm{C}_{18}$. Dengan melihat konsentrasi terbesar dari dua fraksi hasil hidrorengkah yang diperoleh, sehingga dapat diketahui katalis-katalis yang dihasilkan tersebut selektiv terhadap produk pada rantai hidrokarbon $\mathrm{C}_{5}-\mathrm{C}_{11}$ atau $\mathrm{C}_{12}-\mathrm{C}_{18}$. Adapun tabel persentase selektivitas katalis yang menunjukkan pembentukan senyawa - senyawa dengan rantai hidrokarbon $\mathrm{C}_{5}-\mathrm{C}_{11}$ dan $\mathrm{C}_{12}-\mathrm{C}_{18}$ yang dihasilkan Dari hidrorengkah FAME menggunakan katalis $\mathrm{Ni} /$ Zeolit dengan alat GC - MS bisa dilihat pada tabel 1 :

Penentuan aktivitas katalis dilakukan untuk mengetahui kemampuan masingmasing katalis dalam hidrorengkah reaktan menjadi senyawa fraksi pendek. Besarnya persentase aktivitas dari masing-masing katalis pada proses hidrorengkah metil ester oleat ditunjukkan dalam Tabel 2.

Tabel 2. Aktivitas katalis.

\begin{tabular}{clc}
\hline No & \multicolumn{1}{c}{$\begin{array}{c}\text { Jenis } \\
\text { Hidrorengkah }\end{array}$} & $\begin{array}{c}\text { \% Aktivitas Hasil } \\
\text { Hidrorengkah }\end{array}$ \\
\hline 1 & Termal & 54.0074 \\
2 & $\mathrm{H}_{5} \mathrm{NZA}$ & 68.9394 \\
3 & $\mathrm{Ni}-1 \% / \mathrm{H}_{5} \mathrm{NZA}$ & 75.4885 \\
4 & $\mathrm{Ni}-2 \% / \mathrm{H}_{5} \mathrm{NZA}$ & 91.3041 \\
5 & $\mathrm{Ni}-3 \% / \mathrm{H}_{5} \mathrm{NZA}$ & 51.5395 \\
\hline
\end{tabular}

\section{Selektivitas katalis}

Selektivitas katalis didefinisikan sebagai kemampuan katalis untuk mengarah pada jenis produk tertentu. Pada penelitian ini, selektivitas katalis dikelompokkan menjadi dua kelompok senyawa fraksi pendek (gasolin) dengan rantai hidrokarbon $\mathrm{C}_{5}-\mathrm{C}_{11}$ dan senyawa senyawa fraksi sedang (kerosin) dengan rantai hidrokarbon $\mathrm{C}_{12}-\mathrm{C}_{18}$. Dengan melihat konsentrasi terbesar dari dua fraksi hasil hidrorengkah yang diperoleh, sehingga dapat diketahui katalis - katalis yang dihasilkan tersebut selektiv terhadap produk pada rantai hidrokarbon $\mathrm{C}_{5}-\mathrm{C}_{11}$ atau $\mathrm{C}_{12}-\mathrm{C}_{24}$.

Berdasarkan tabel 3, Katalis Ni$2 \% / \mathrm{H}_{5} \mathrm{NZA}$ lebih selektiv terhadap konversi MEFA menjadi senyawa fraksi hidrokarbon dengan rantai atom $\mathrm{C}_{5}-\mathrm{C}_{11}$ dibandingkan dengan katalis $\mathrm{Ni}-$ $1 \% / \mathrm{H}_{5} \mathrm{NZA}$ dan $\mathrm{Ni}-3 \% / \mathrm{H}_{5} \mathrm{NZA}$, hal ini dapat disimpulkan bahwa dengan adanya modifikasi logam Ni memberikan kontribusi jika dibandingkan dengan tanpa logam Ni.

Pada saat FAME dilakukan proses hidrorengkah sesuai kromatogram yang telah disebutkan diatas akan menghasilkan produk dengan rantai yang lebih rendah sehingga kecil kemungkinan untuk menghasilkan produk dengan jumlah atom C lebih banyak. 
Tabel 3. Persentase selektivitas produk dari masing-masing katalis terhadap pembentukan senyawa - senyawa dengan rantai hidrokarbon $\mathrm{C}_{5}-\mathrm{C}_{11}$ dan $\mathrm{C}_{12}-\mathrm{C}_{18}$.

\begin{tabular}{cccccc}
\hline $\begin{array}{c}\text { Selektivitas katalis } \\
\text { pada pembentukan }\end{array}$ & \multirow{2}{*}{ Termal } & $\mathrm{H}_{5} \mathrm{NZA}$ & $\mathrm{Ni}-1 \% / \mathrm{H}_{5} \mathrm{NZA}$ & $\mathrm{Ni}-2 \% / \mathrm{H}_{5} \mathrm{NZA}$ & $\mathrm{Ni}-3 \% / \mathrm{H}_{5} \mathrm{NZA}$ \\
\hline $\mathrm{C}_{5}-\mathrm{C}_{11}$ & $16.95 \%$ & $7.35 \%$ & $19.42 \%$ & $37.33 \%$ & $5.27 \%$ \\
$\mathrm{C}_{12}-\mathrm{C}_{18}$ & $3.87 \%$ & $8.52 \%$ & $8.15 \%$ & $11.54 \%$ & $2.60 \%$ \\
\hline
\end{tabular}

Tabel 4. Daftar senyawa hasil hidrorengkah asam oleat (FAME) melalui uji GC - MS

\begin{tabular}{|c|c|c|c|c|c|c|}
\hline \multirow[b]{2}{*}{ No } & \multirow[b]{2}{*}{ Nama senyawa } & \multicolumn{5}{|c|}{$\%$ Konsentrasi produk pada setiap katalis } \\
\hline & & Termal & $\mathrm{H}_{5} \mathrm{NZA}$ & $\begin{array}{l}\mathrm{Ni}-1 \% / \\
\mathrm{H}_{5} \mathrm{NZA}\end{array}$ & $\begin{array}{l}\mathrm{Ni}-2 \% / \\
\mathrm{H}_{5} \mathrm{NZA}\end{array}$ & $\begin{array}{r}\mathrm{N}-3 \% / \\
\mathrm{H}_{5} \mathrm{NZA}\end{array}$ \\
\hline 1 & 1-Nonene $\mathrm{C}_{9} \mathrm{H}_{18}$ & 1.9371 & 0.3790 & 2.8032 & 1.0723 & 0.5709 \\
\hline 2 & Nonane $\mathrm{C}_{9} \mathrm{H}_{20}$ & 3.7141 & 0.0343 & 4.9403 & 5.9132 & 0.8944 \\
\hline 3 & Bicyclo $\mathrm{C}_{8} \mathrm{H}_{14}$ & 5.0647 & 0.8859 & 5.4642 & 10.7060 & 1.3921 \\
\hline 4 & 1-Decene $\mathrm{C}_{10} \mathrm{H}_{20}$ & 0.6766 & 3.2639 & 3.9143 & 10.4511 & 1.1038 \\
\hline 5 & Spiro[2.4]heptan-4-one $\mathrm{C}_{7} \mathrm{H}_{10} \mathrm{O}$ & 2.3032 & 0.6793 & 2.3934 & 0.0437 & 0.6295 \\
\hline 6 & 2-Decene $\mathrm{C}_{10} \mathrm{H}_{20}$ & 0.6506 & 0.5870 & 1.5526 & 0.1086 & 0.3262 \\
\hline 7 & Metyl trans 6-heptenoat $\mathrm{C}_{8} \mathrm{H}_{14} \mathrm{O}_{2}$ & 1.3351 & 3.8317 & 0.9658 & 5.2864 & - \\
\hline 8 & 1-Undecene $\mathrm{C}_{11} \mathrm{H}_{22}$ & 1.2581 & 1.1833 & 0.7563 & 2.9512 & 0.1755 \\
\hline 9 & Dodecane $\mathrm{C}_{12} \mathrm{H}_{26}$ & 0.6528 & 0.0388 & 0.6546 & 1.5829 & 0.1718 \\
\hline 10 & 4-Undecene $\mathrm{C}_{11} \mathrm{H}_{22}$ & 1.4906 & 0.0821 & 0.3168 & 1.3672 & 0.1366 \\
\hline 11 & 1-Dodecene $\mathrm{C}_{12} \mathrm{H}_{24}$ & 0.7079 & 1.4308 & - & 1.3444 & 0.1069 \\
\hline 12 & Tridecana $\mathrm{C}_{13} \mathrm{H}_{28}$ & 0.1366 & - & 0.5627 & 1.0861 & 0.0920 \\
\hline 13 & 2-Dodecene $\mathrm{C}_{12} \mathrm{H}_{24}$ & 0.2252 & - & 0.3043 & 0.6124 & - \\
\hline 14 & Methyl ester $\mathrm{C}_{10} \mathrm{H}_{18} \mathrm{O}_{2}$ & 0.3373 & - & 0.2334 & 0.4286 & - \\
\hline 15 & 3-Tetradecene $\mathrm{C}_{14} \mathrm{H}_{28}$ & 0.5105 & - & 0.1289 & 0.4515 & - \\
\hline 16 & Tridecana $\mathrm{C}_{13} \mathrm{H}_{28}$ & 0.0363 & - & 0.2700 & 0.8148 & - \\
\hline 17 & Methyl ester $\mathrm{C}_{11} \mathrm{H}_{22} \mathrm{O}_{2}$ & 0.2960 & 1.4488 & 0.6409 & 1.0055 & 0.6105 \\
\hline 18 & 3-Hexadecene $\mathrm{C}_{16} \mathrm{H}_{32}$ & 0.2611 & 0.9990 & 0.34680 & 0.2677 & 0.0894 \\
\hline 19 & Heptadecana $\mathrm{C}_{17} \mathrm{H}_{36}$ & 0.5851 & 3.1193 & 1.6858 & 1.5232 & 0.3562 \\
\hline 20 & Methyl ester $\mathrm{C}_{13} \mathrm{H}_{26} \mathrm{O}_{2}$ & 1.7079 & 1.2421 & 1.3016 & 0.7720 & 2.0048 \\
\hline 21 & Tetradecaniid acid $\mathrm{C}_{14} \mathrm{H}_{28} \mathrm{O}_{2}$ & 0.2456 & 0.2372 & 0.2057 & 0.1123 & 0.1457 \\
\hline 22 & Methyl ester $\mathrm{C}_{14} \mathrm{H}_{28} \mathrm{O}_{2}$ & 0.1698 & 0.1045 & 0.2288 & 0.0998 & - \\
\hline 23 & 8-Heptadecene $\mathrm{C}_{17} \mathrm{H}_{34}$ & 0.1097 & 0.8748 & 1.0722 & 0.7473 & 0.5685 \\
\hline 24 & 8-Heptadecene $\mathrm{C}_{17} \mathrm{H}_{34}$ & 0.1002 & - & 1.5651 & 1.2348 & 0.6547 \\
\hline 25 & Octadecane $\mathrm{C}_{18} \mathrm{H}_{38}$ & 0.0595 & 0.9700 & 0.5222 & 0.4055 & 0.2312 \\
\hline 26 & Methyl ester $\mathrm{C}_{15} \mathrm{H}_{30} \mathrm{O}_{2}$ & 0.0411 & 0.1707 & 0.1587 & 0.8026 & 0.2624 \\
\hline 27 & 2-Pentadecanone $\mathrm{C}_{18} \mathrm{H}_{36} \mathrm{O}$ & 0.1884 & 0.6170 & 0.4599 & 0.2786 & 0.1081 \\
\hline 28 & 9,17-Octadecadienal $\mathrm{C}_{18} \mathrm{H}_{32} \mathrm{O}$ & 0.5828 & 2.4592 & 0.1247 & 1.1439 & 6.0355 \\
\hline
\end{tabular}

Berdasarkan tabel 3, Katalis $\mathrm{Ni}-$ $2 \% / \mathrm{H}_{5} \mathrm{NZA}$ lebih selektiv terhadap konversi MEFA menjadi senyawa fraksi hidrokarbon dengan rantai atom $\mathrm{C}_{5}-\mathrm{C}_{11}$ dibandingkan dengan katalis $\mathrm{Ni}-$ $1 \% / \mathrm{H}_{5} \mathrm{NZA}$ dan $\mathrm{Ni}-3 \% / \mathrm{H}_{5} \mathrm{NZA}$, hal ini dapat disimpulkan bahwa dengan adanya Online ISSN: 2528-0422 modifikasi logam $\mathrm{Ni}$ memberikan kontribusi jika dibandingkan dengan tanpa logam Ni.

Pada saat FAME dilakukan proses hidrorengkah sesuai kromatogram yang telah disebutkan diatas akan menghasilkan produk dengan rantai yang lebih rendah 
sehingga kecil kemungkinan untuk menghasilkan produk dengan jumlah atom C lebih banyak.

Senyawa baru yang dihasilkan dari proses hidrorengkah (tabel 4) adalah dari $\mathrm{C}_{8}$ (bicyclo) sampai $\mathrm{C}_{18}$ (octadienal) menunjukkan bahwa senyawa bicyclo, nonana, 1-nonena, 1-decena dan heptadecana adalah senyawa - senyawa yang memiliki selektivitas paling tinggi jika dibandingkan dengan senyawa senyawa lainnya dalam setiap katalis. Senyawa bicyclo, 1-nonene dan nonane merupakan senyawa hidrokarbon dengan rantai paling rendah yang didapat sebagai fraksi cair dari hasil hidrorengkah. Besarnya konsentrasi bicyclo, 1-nonene dan nonane yang dihasilkan tampak dipengaruhi oleh adanya pengembanan logam Ni yang divariasi. Semakin banyak logam Ni yang teremban, konsentrasi yang dihasilkan juga semakin meningkat. Prediksi dari peristiwa hidrorengkah ini adalah terjadinya hidrogenolisis ester pada metil ester (reaktan) terlebih dahulu dengan membentuk alkohol primer dan metanol. Setelah itu alkohol primer mengalami hidrogenasi lebih lanjut sehingga terbentuk alkana. Alkana yang terbentuk ini kemudian mengalami reaksi cracking pada proses hidrorengkah dengan adanya katalis Ni/H5-NZA ((Abdulloh, Purkan, \& Hardiansyah, 2017).

Terbentuknya senyawa bicyclo, 1nonene dan nonane diprediksi dengan terjadinya proses cracking pada reaktan melalui terbentuknya alkana terlebih dahulu kemudian alkana yang dihasilkan membentuk ion karbonium sebagai intermediet dengan bantuan dari katalis $\mathrm{Ni} / \mathrm{H}_{5}-\mathrm{NZA}$. Setelah terbentuk intermediet

\section{Daftar Pustaka}

Abdulloh, A., Purkan, P., \& Hardiansyah, N. (2017). Preparasi dan karakterisasi $\alpha-\mathrm{Fe}_{2} \mathrm{O}_{3}$ /zeolit $\mathrm{Y}$ untuk reaksi perengkahan asam palmitat. Jurnal Kimia Riset, 2, 69-76. kemudian terjadi pemotongan $\beta$-scission yang menghasilkan fraksi olefin dan ion karbonium dengan rantai hidrokarbon yang lebih pendek. Selanjutnya terjadi peristiwa transfer hidrogen (hydride transfer) pada ion karbonium sehingga terbentuk senyawa parafin. Adanya produk fraksi panjang yang terbentuk dengan konsentrasi yang lebih rendah, ini menandakan bahwa proses hidrorengkah FAME yang telah dilakukan dengan katalis $\mathrm{Ni} / \mathrm{H}_{5}-\mathrm{NZA}$ sudah bisa dikatakan menghasilkan produk hidrokarbon fraksi pendek $\left(\mathrm{C}_{5}-\mathrm{C}_{11}\right)$ dengan maksimal.

\section{Kesimpulan}

Zeolit yang telah diimpregnasikan dengan logam $\mathrm{Ni}$ mengalami penurunan rasio $\mathrm{Si} / \mathrm{Al}$. Konsentrasi Ni yang teremban pada zeolit meningkat seiring meningkatnya konsentrasi $\mathrm{Ni}$ yang diembankan. Keasaman katalis $\mathrm{Ni} / \mathrm{H}_{5}-$ NZA meningkat seiring dengan meningkatnya konsentrasi $\mathrm{Ni}$ yang teremban pada zeolit.

$\mathrm{Ni}-2 \% / \mathrm{H}_{5} \mathrm{NZA}$ memiliki aktivitas tertinggi dan $\mathrm{H}_{5}-\mathrm{NZA}$ memiliki aktivitas terendah. Katalis $\mathrm{Ni}-2 \% / \mathrm{H}_{5} \mathrm{NZA}$ lebih selektiv terhadap pembentukan produk hidrokarbon fraksi pendek $\left(\mathrm{C}_{5}-\mathrm{C}_{11}\right)$ dibandingkan dengan katalis $\mathrm{Ni} / \mathrm{H}_{5}-\mathrm{NZA}$ lainnya dan lebih mengarah pada pembentukan produk alkana dan alkena.

\section{Ucapan Terima Kasih}

Penelitian ini saya ucapkan terima kasih kepada Dr. Donatus Setyawan, M.Si dan Novita Adarini, S.Si., M.Si penelitian 2010

Abiney L. Cardoso. 2008. Esterification of Oleic Acid for Biodiesel Production Catalyzed by $\mathrm{SnCl}_{2}:$ A Kinetic Investigation. Brazil: Departament of Chemistry, Federal University of Viçosa, Minas Gerais, , 
Astutik, D.R. 2005. "Aktivitas Katalis NZA dan $\mathrm{H}_{5} \mathrm{NZA}$ dalam Reaksi Konversi Jelantah menjadi Senyawa Fraksi Bahan Bakar pada Variasi Jenis Alkohol sebagai Umpan Pancingan". Skripsi. Jember: FMIPA Universitas Jember.

Catherine, M. 2002. “ Pengaruh kadar logam Nikel terhadap aktivitas katalis $\mathrm{Ni} /$ Zeolit-Y dalam reaksi hidrorengkah minyak bumi, Tesis, Universitas Gadjah Mada.

Hasyim, W. 2007. Studi Aktivitas dan Selektivitas Katalis $\mathrm{Ni}(\mathrm{II}) / \mathrm{H}_{5} \mathrm{NZA}$ dan $\mathrm{Zn}(\mathrm{II}) / \mathrm{H}_{5} \mathrm{NZA}$ dalam Konversi Plastik menjadi Senyawa Fraksi Bahan Bakar Cair. Skripsi, FMIPA Universitas Jember.
Hendrawati,T. Y 2017, Pengaruh Suhu terhadap Kandungan Asam Palmitat pada proses fraksinasi Palm Stearin.Jurnal.umj.ac.id/index.php/se mnastek.

Kadarwati, S., 2013 Kinetics and Mechanism of Ni/Zeolite - Catalyzed Hydrocracking of Palm Oil into Bio Fuel. Department of Chemistry, Semarang State University. Indo.J.Chem., 2013 , 13, 77 - 85.

Sie,Tiong, S., 1992, Acid-Catalyzed Cracking of Paraffins Hydrocarbons.1. Discussion of Existing Mechanisms and Proposal of a New Mechanism, Journal Industrial and Enginering Chemical Ressearch, 31, 1881-1889. 